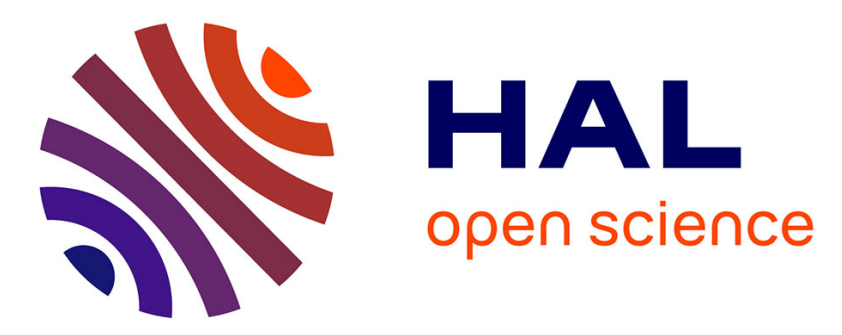

\title{
An Early Record of a Vesselless Angiosperm from the Middle Cenomanian of the Envigne Valley (Vienne, Western France)
}

A. Boura, G. Saulnier, D. de Franceschi, B. Gomez, V. Daviero-Gomez, D. Pons, Géraldine Garcia, N. Robin, J-M Boiteau, Xavier Valentin

\section{To cite this version:}

A. Boura, G. Saulnier, D. de Franceschi, B. Gomez, V. Daviero-Gomez, et al.. An Early Record of a Vesselless Angiosperm from the Middle Cenomanian of the Envigne Valley (Vienne, Western France). IAWA Journal, 2019, 40 (3), pp.530-550. 10.1163/22941932-40190238 . hal-02871851v2

\section{HAL Id: hal-02871851 \\ https://hal.science/hal-02871851v2}

Submitted on 12 May 2021

HAL is a multi-disciplinary open access archive for the deposit and dissemination of scientific research documents, whether they are published or not. The documents may come from teaching and research institutions in France or abroad, or from public or private research centers.
L'archive ouverte pluridisciplinaire HAL, est destinée au dépôt et à la diffusion de documents scientifiques de niveau recherche, publiés ou non, émanant des établissements d'enseignement et de recherche français ou étrangers, des laboratoires publics ou privés. 


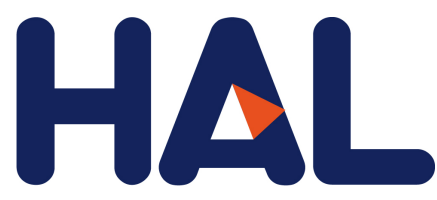

archives-ouvertes

\section{An Early Record of a Vesselless Angiosperm from the Middle Cenomanian of the Envigne Valley (Vienne, Western France)}

A. Boura, G. Saulnier, D. de Franceschi, B. Gomez, V. Daviero-Gomez, D. Pons, Géraldine Garcia, N. Robin, J-M. Boiteau, Xavier Valentin

\section{To cite this version:}

A. Boura, G. Saulnier, D. de Franceschi, B. Gomez, V. Daviero-Gomez, et al.. An Early Record of a Vesselless Angiosperm from the Middle Cenomanian of the Envigne Valley (Vienne, Western France). IAWA Journal, Brill publishers, 2019, 40 (3), pp.2-21. 10.1163/22941932-40190238 . hal-02871851v2

\section{HAL Id: hal-02871851 https://hal.archives-ouvertes.fr/hal-02871851v2}

Submitted on 12 May 2021

HAL is a multi-disciplinary open access archive for the deposit and dissemination of scientific research documents, whether they are published or not. The documents may come from teaching and research institutions in France or abroad, or from public or private research centers.
L'archive ouverte pluridisciplinaire HAL, est destinée au dépôt et à la diffusion de documents scientifiques de niveau recherche, publiés ou non, émanant des établissements d'enseignement et de recherche français ou étrangers, des laboratoires publics ou privés. 


\title{
An early record of a vesselless angiosperm from the middle Cenomanian of the Envigne valley (Vienne, Western France)
}

\author{
A. Boura ${ }^{1}{ }^{*}$, G. Saulnier ${ }^{1}$, D. De Franceschi ${ }^{1}$, B. Gomez ${ }^{2}$, V. Daviero-Gomez ${ }^{2}$, \\ D. Pons ${ }^{1}$, G. Garcia ${ }^{3}$, N. Robin ${ }^{1}$, J-M. Boiteau ${ }^{4}$, and X. Valentin ${ }^{3,5}$ \\ ${ }^{1}$ CR2P, UMR7207, MNHN, Sorbonne Université, CNRS, 57 rue Cuvier, CP 48, \\ 75005 Paris, France. \\ ${ }^{2}$ LGL, UMR 5276, Université Lyon 1, 69622 Villeurbanne, France. \\ 3 PALEVOPRIM, UMR7262 CNRS INEE, Université de Poitiers, 6 rue Michel-Brunet, \\ 86073 Poitiers cedex, France. \\ 481 Avenue Jean Mermoz, 86100 Châtellerault, France. \\ ${ }^{5}$ Palaios, Research Association, 86300 Valdivienne, France. \\ *Corresponding author; e-mail: anais.boura@ sorbonne-universite.fr
}

Accepted for publication: 27 January 2019 - Available online: April 2019

\begin{abstract}
Thousands of silicified wood fragments were recently collected from the middle Cenomanian of Vienne in western France at less than $10 \mathrm{~km}$ away from a historical locality where in 1870 the French geologist Alphonse Le Touzé de Longuemar reported silicified wood. The plant assemblage is very diverse, and includes several species of ferns, conifers, and angiosperms. We describe and discuss the systematic affinities of a new vesselless angiosperm. Many of its characters are shared by extant and fossil Winteraceae. Nevertheless, the absence of uniseriate rays makes the anatomy of these specimens unique. Its combination of characters justifies the establishment of a new genus of vesselless fossil angiosperm wood of uncertain affinity, Sherwinoxylon gen. nov.
\end{abstract}

Keywords: Fossil wood, Winteraceae, Cretaceous, Sherwinoxylon gen. nov.

\section{INTRODUCTION}

In recent years, thousands of silicified wood fragments have been collected from the middle Cenomanian of two localities in the Envigne valley (Vienne department, western France) (Robin et al. 2018). Only trunks and branches of various lengths and diameters have been preserved. Both fossil assemblages are exceptional in their high plant diversity and the exquisite tissue preservation, as well as in their association with animal fossils. For instance, some of the petrified woods have allowed for the preservation of the oldest shipworms described with soft parts (Robin et al.2018). Shipworms, bivalve molluscs of the family Teredinidae, are notorious for boring into wood that is immersed in sea water.

Conifers are the most abundant and diversified fossil wood in this assemblage, representing around $90 \%$ and at least five different taxa. They consist of large logs transported into an estuarine or a near-shore environment. Although angiosperms are less 
abundant (only 9.8\%) and have smaller diameters, they have a higher diversity with at least nine different taxa (Saulnier et al.2018). Angiosperm pollen grains and leaves have been frequently reported from the Cenomanian of western France (Crié 1884; Juignet \& Médus 1971; Azéma et al. 1972; Laing 1975; Pons et al. 1980; Gomez et al. 2004, 2008; Peyrot et al. 2005; Néraudeau et al. 2005, 2008, 2013, 2017; Valentin et al. 2014; Fleury et al. 2017), but they were not yet related to fossil wood. So far described contemporary wood consisted only of lignitized conifer genera (Néraudeau et al.2003, 2008, 2013, 2017; Fleury et al.2017). These two fossil plant assemblages are thus of great interest in the understanding of the spread and rise to dominance of woody angiosperms in Europe and worldwide during the Cretaceous. In this context, vesselless angiosperms are also of particular interest, and here we describe a new form genus in this category of homoxylous woods.

A vesselless angiosperm wood is a "wood without vessel elements, composed only of imperforate tracheary elements and parenchyma [...], Amborellaceae, Tetracentraceae, Trochodendraceae, Winteraceae." (IAWA Committee 1989). Nevertheless, the presence of perforated vessel elements was recently highlighted in Trochodendraceae (Ren et al. 2007; Li et al. 2011) or in Sarcandra Gardner (Chloranthaceae) (Carlquist 1987). In other genera such as Amborella Baill., Bubbia Tiegh. or Drimys J.R. Forst. ex G. Forst., tracheary cells show a tendency toward differentiation of end wall pitting (Feild et al. 2000; Carlquist \& Schneider 2002). According to the last angiosperm phylogeny (Angiosperm Phylogeny Group 2016) and data on wood structure (Carlquist 1975, 2001; InsideWood 2004-onwards; Wheeler 2011), vesselless wood is found in the basal angiosperms (ANA grade with Amborellaceae), Magnoliids (Winteraceae), Chloranthales (Chloranthaceae) and in one of the early branching eudicot clades, Trochodendrales (Trochodendraceae, including former Tetracentraceae) (Fig. 1).

The wood structure in these different vesselless angiosperms clearly shows similarity with that of homoxylous wood clades in gymnosperms (e.g. conifers). This character has long been considered to be a plesiomorphic state of the water conducting elements in the secondary xylem as the families showing it were found in the basal groups of angiosperms in former phylogenies (e.g., Young 1981; Hufford \& Crane 1989; Chase et al. 1993). In the APG IV (Angiosperm Phylogeny Group 2016), Amborella trichopoda Baill. represented a sister group to all other angiosperms. Baas and Wheeler (1996) argued in favour of vessellessness being basal in angiosperms, with unparsimoneous parallel origins of vessels. On the other hand, homoxylous wood in angiosperms might also result from convergent environmental pressures. Interestingly numerous plants showing this character grow in temperate to subtropical moist environments with a high annual temperature amplitude. Vesselless wood might be seen as an adaptation to frost-prone environments as Feild et al. (2002) suggested for Winteraceae. Therefore, vesselless wood might be either an ancestral or a derived character depending on the family considered, and thus its phylogenetic significance within angiosperms still remains controversial.

The fossil record of most vesselless angiosperm families is quite ancient: early Cretaceous for Winteraceae with the pollen type Walkeripollis gabonensis Doyle, Hotton \& 


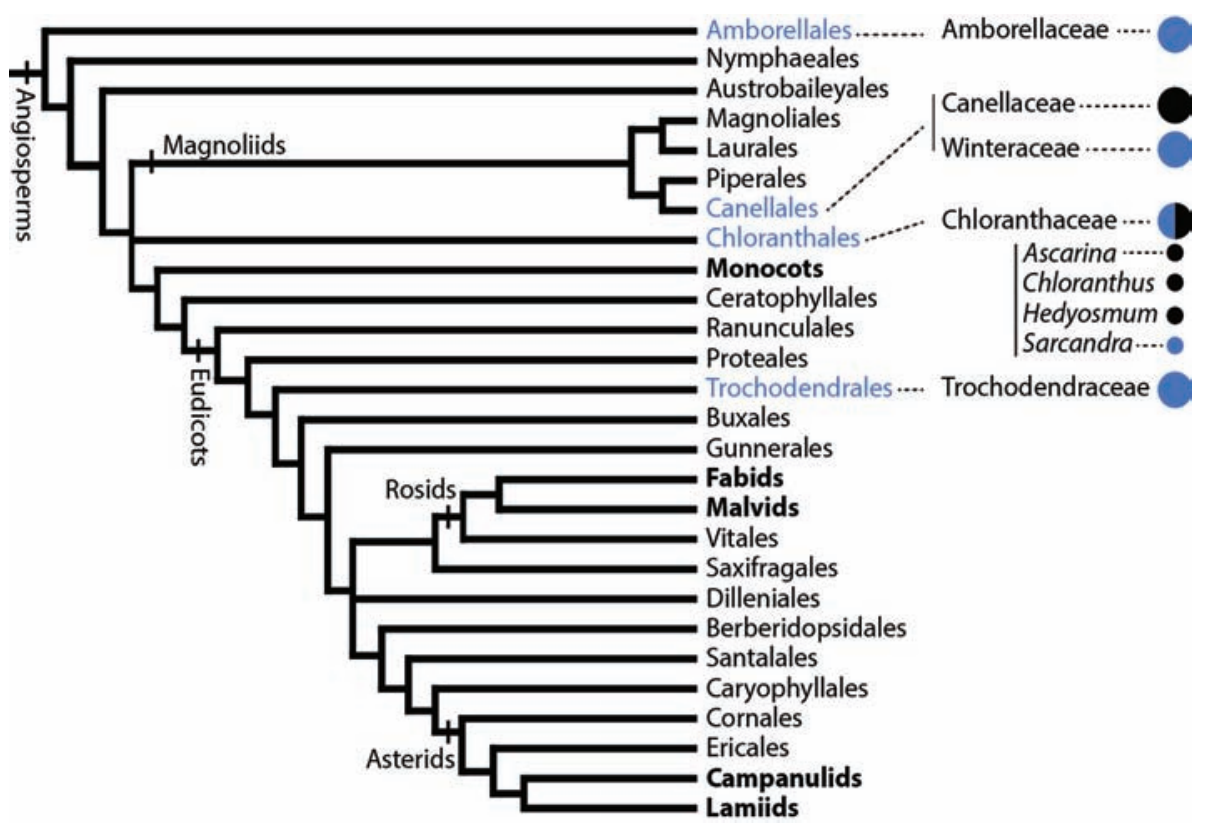

Figure 1. Occurrence of vesselless wood in angiosperms. Blue circle $=$ homoxylous or vesselless, black circle $=$ heteroxylous or vessel-bearing. Modified from Angiosperm Phylogeny Group (2016).

J.V.Ward (Doyle et al. 1990) and for Chloranthaceae (Barremian-Aptian) with the pollen type Asteropollis Hedlund \& Norris related to the extant genus Hedyosmum Sw. (Friis et al. 1994; Tanaka 2008); late Cretaceous (early Coniacian) for Trochodendraceae with the flower Archaestella verticillatus Takahashi, Herendeen \& Xiao (Takahashi et al. 2017).

The family Amborellaceae includes a single genus and species, Amborella trichopoda, which grows as understory shrubs that are endemic in New Caledonia. No fossil record for this family is known so far.

The family Winteraceae includes 6 valid and 3 unresolved or synonymous genera according to The Plant List (2013) of shrubs, trees and lianas in the montane tropics and temperate rainforests, mostly in the Southern Hemisphere occurring from southern North America to South America (Mexico, Ecuador, Venezuela, Brazil, Chile, Juan Fernandez Islands), Madagascar, the Philippines, Borneo, Sulawesi, New Guinea, the Solomon Islands, New Caledonia, eastern Australia, Tasmania, and New Zealand (Christenhusz et al. 2017).

Although extant Winteraceae are only distributed in the Southern Hemisphere, fossils attributed to this family (leaves, wood, and pollen) have been reported from both Northern and Southern Hemispheres (for a review see Doyle 2000, Friis et al. 2011, and Grímsson et al. 2018). Winteraceae have a unique type of pollen/tetrad easily recognizable (Walker \& Walker 1984; Grímsson et al. 2017). During the Cretaceous winteraceous pollen have been reported from the late Barremian-early Aptian 
of Gabon (Doyle et al. 1990), Albian of Israel (Walker et al. 1983; Schrank 2013), middle Campanian (Dettmann \& Jarzen 1990), and Maastrichtian of Australia (Stover \& Partridge 1973), and the latest Cretaceous of New Zealand (Mildenhall \& Crosbie 1979). In the Southern Hemisphere, Poole and Francis (2000) described Winteroxylon jamesrossi Poole \& Francis, a fossil wood from the Santonian-Campanian of Antarctica. A few fossils attributed to Winteraceae have been described outside the range of extant members as, for example, the type species of Winteroxylon Gottwald, W. mundlosi Gottwald from the Eocene of Europe (Gottwald 1992). Doyle (2000) suggested that the geographical range of the family could have been larger than previously thought and may have included Laurasia or that the European fossils were a wrong attribution. The recent report of Winteraceae pollen tetrads from the early Paleocene of western Greenland (Grímsson et al. 2018) has brought new elements to the understanding of the past distribution of this family and has challenged recent theories that interpret the Winteraceae as a Southern Hemisphere clade with a possible origin in Northern Gondwana (Doyle \& Endress 2000; Thomas et al. 2014). There are two occurrences of fossil leaves attributed to Winteraceae in the Northern Hemisphere: the first from the mid-Cretaceous of Nebraska (Upchurch \& Dilcher 1990) and the second from the Eocene of Oregon (Chaney \& Sanborn 1933). Nevertheless, winteraceous leaves are not very distinctive (Doyle 2000), and ancient records should be re-examined, in particular with regard to cuticle characters.

Extant Chloranthaceae are distributed in Southeast Asia, Madagascar, Central and South America, and the Caribbean Islands. Unequivocal fossils include diverse inflorescences, flowers and fruits, that were common worldwide (for reviews see Eklund et al. 2004 and Doyle \& Endress 2014). A single fossil wood species has been described in Chloranthaceae, Mulleroxylon eupomatioides Page from the Late Cretaceous of North America (Page 1968), but its structure is heteroxylous as in several extant Chloranthaceae genera.

Extant Trochodendraceae are distributed in eastern Asia, from northeastern India to Japan, and only comprise two monospecific genera, Trochodendron Siebold \& Zucc. and Tetracentron Oliv. (Endress 1986). The geographical range of this family was much larger in the past. Unequivocal fossils of flowers, infructescences and wood have been reported from North America, Greenland, Iceland, and Asia (for reviews see Suzuki et al. 1991 and Takahashi et al.2017). The oldest vesselless wood attributed to Trochodendraceae is Tetracentronites Page from the Maastrichtian of North America (Page 1970).

The aim of this article is to describe the wood of a vesselless angiosperm collected from the middle Cenomanian of the Envigne valley in western France. Systematic affinities with extant and fossil vesselless angiosperms are discussed.

In later publications we describe the remaining conifer and angiosperm wood types and provide more detailed analyses of the fossils and their paleoenvironment. 

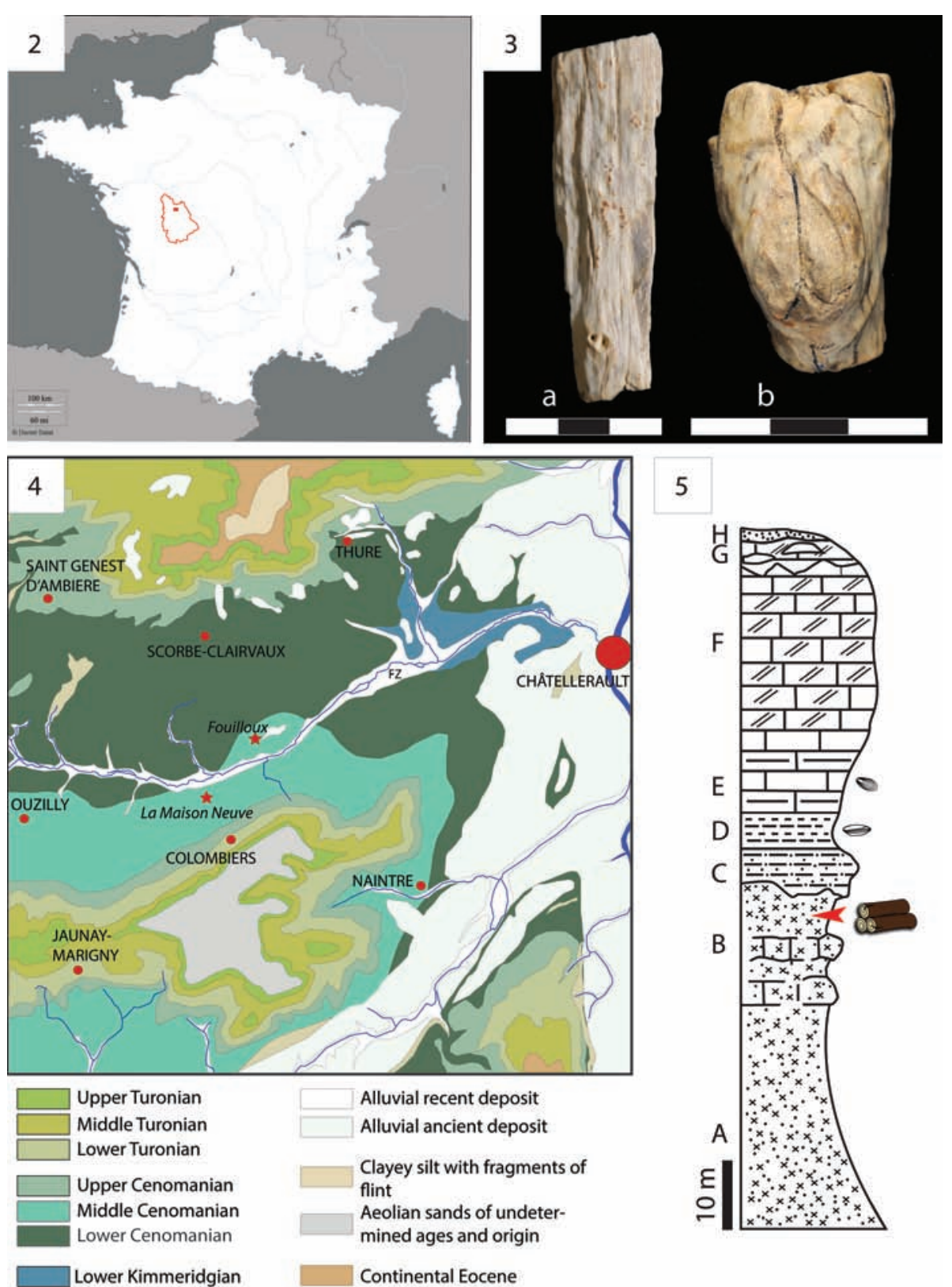

Figure 2-5. - 2: Map of France showing the Vienne department (outline in red), the type locality, Scorbé Clairvaux, is included in the red rectangle. The area represented by this rectangle is magnified in 4. -3 : Two fossil wood samples, $a=$ UP.SCF.17.004, $b=$ UP.SCF.17.007. Scale bars $=3 \mathrm{~cm}$. Multiseriate rays are visible to the naked eye. -4 : Simplified geologic map showing the two new localities: Fouilloux (type locality, Scorbé-Clairvaux) and 'La Maison Neuve' 


\section{MATERIAL AND METHODS}

Several thousand fossil woods were collected during fieldwork campaigns in 2015 and 2016 from the green sandstones and claystones of La Pallu, Envigne valley, Vienne department, France (Fig. 2, 4 \& 5). They are all silicified (Fig. 3a \& 3b). For a detailed geological setting see Robin et al. (2018).

Around a thousand samples were examined with a stereomicroscope. Fifteen of the latter were identified to the new taxon described here. Transverse, radial and tangential sections of the fossil wood were prepared from five samples at the Muséum national d'Histoire naturelle (MNHN) of Paris, France following standard techniques (Jones $\&$ Rowe 1999). They were described following the IAWA Hardwood List (IAWA Committee 1989). Botanical affinities were determined using the InsideWood database (InsideWood 2004-onwards; Wheeler 2011) and literature on fossil and extant vesselless angiosperms (e.g., Metcalfe \& Chalk 1950, 1987; Carlquist 1975, 2001; Suzuki et al. 1991; Gregory et al. 2009 and references therein; for a complete list of references see Table 1).

All microscopic slides, including one transverse, one radial longitudinal and one tangential longitudinal section per specimen and remains of the original specimens are housed in the paleontological collections of the Université de Poitiers (Centre de Valorisation des collections scientifiques de l'Université de Poitiers), France under the numbers UP.SCF.17.003 to UP.SCF.17.007. Photographs of the fossil wood sections were taken with a Nikon D300 digital camera attached to a Nikon Eclipse 80i microscope.

\section{RESULTS}

'Family unknown'

SHERWINOXYLON Boura \& Saulnier, gen. nov.

Type: Sherwinoxylon winteroides Boura \& Saulnier, sp.nov. (UP/SCF.17.004 (field number: VI83) $(6.747 \times 1.886 \mathrm{~cm}))$.

Repository: Université de Poitiers.

Type locality: Fouilloux, Scorbé-Clairvaux.

Stratigraphic horizon: green sandstones of La Pallu, middle Cenomanian.

(Colombiers) are illustrated by red stars. Jaunay-Marigny represents the historical locality where in 1870 the French geologist A. Le Touzé de Longuemar has reported for the first time silicified wood. Modified from Médioni et al. (1974) and Bourgueil et al. (1976). - 5: Stratigraphic column modified after Gabilly \& Cariou (1997): A, claystones and white sandstones of Vierzon (lower Cenomanian); B, green sandstones and C, sandy-claystones of La Pallu (middle Cenomanian); D, plastic claystones and white marlstones with oysters (upper Cenomanian); E, clayey limestones and chalkstones with Inoceramus labiatus (lower Turonian); F, white tufa (micaceous glauconitic chalk, middle Turonian); G-H, altered yellow tufa and clayey sandstones with silicified nodules with plants (Gomez et al. 2019) (upper Turonian). Studied wood remains were collected from the green sandstones and claystones of La Pallu (indicated in B). 
Etymology: In honour of Professor Sherwin Carlquist for his great works on wood anatomy in general and on vesselless angiosperms in particular.

Diagnosis: Vesselless wood. Tracheids with circular to elliptical, closely spaced uniseriate bordered pits, present in both radial and tangential walls. Rays multiseriate. Ray cells with numerous simple to weakly bordered pits. Uniseriate rays absent. Axial parenchyma abundant, diffuse to diffuse-in-aggregates.

Sherwinoxylon winteroides Boura \& Saulnier, sp. nov.

Holotype: UP/SCF.17.004 (field number: VI83) $(6.7 \times 1.9 \mathrm{~cm})$.

Additional specimens: UP/SCF.17.003 (field number: VI16) (2.7 cm diam.), UP/ SCF.17.005 (field number: VI87) $(5.668 \times 1.606 \mathrm{~cm}), \mathrm{UP} / \mathrm{SCF} .17 .006$ (field number: VI147) $(6.967 \times 2.691 \mathrm{~cm})$, UP/SCF.17.007 (field number: VI183) $(3.637 \times 2 \times 4.27$ $\mathrm{cm})$ (all three thin transverse, tangential and radial sections).

Repository: Université de Poitiers.

Type locality: Fouilloux, Scorbé-Clairvaux.

Stratigraphic horizon: green sandstones of La Pallu, middle Cenomanian.

Etymology: To highlight the resemblance between the species and modern Winteraceae.

Diagnosis: Vesselless wood with indistinct growth rings. Tracheids medium- to thickwalled with exclusively circular to elliptical uniseriate bordered pits, more abundant in the radial than tangential walls. Rays multiseriate, up to 9 cells wide, high, composed of square cells with up to four upright marginal cells. Ray cells thickwalled with abundant simple to weakly bordered pits. Axial parenchyma diffuse and diffuse-in-aggregates .

\section{Description}

Homoxylous and pycnoxylic fossil wood (Fig. $7 \& 8$ ). Faint growth-ring boundaries marked by 1 to 3 rows of flattened latewood tracheids with thicker walls (Fig. 9). Tracheids relatively thick-walled; walls $2-13 \mu \mathrm{m}$ (average $6.7 \pm 1.7 \mu \mathrm{m}$ ) thick; about $2 \mathrm{~mm}$ long; tangential diameter 15-48 $\mu \mathrm{m}$ (average $29.9 \pm 4.9 \mu \mathrm{m}$ ) (Fig. 9 \& 10). Tracheid-tracheid pits bordered, more abundant in radial walls (Fig. 15 \& 16) but also common in the tangential walls (Fig. 13 \& 14); uniseriate, circular to elliptic all along the tracheid body and in overlapping ends; pit apertures elliptic and oblique with different orientations from one tracheid to its neighbour, which gives a fairly characteristic cross-shaped appearance to the apertures in radial sections. Axial parenchyma abundant, irregularly distributed; diffuse to diffuse-in-aggregates (Fig. 8 \& 11); in strands of up to 16 cells. Uniseriate rays absent. Rays 3- to 9-seriate (Fig. 12 \& 13), mostly 4- to 5-seriate, composed of square cells, with 1 to 8 rows of upright marginal cells (Fig. 17); a few procumbent cells are sometimes visible among square cells; larger rays $1.03-10.53 \mathrm{~mm}$ high (average $4.24 \pm 1.65 \mathrm{~mm}$ ) and $10-170 \mu \mathrm{m}$ wide (average $80 \pm 14 \mu \mathrm{m}$ ) (Fig. $12 \&$ 13). Ray cell walls thick (Fig. 18), with numerous small, simple to weakly bordered pits, without particular arrangement (Fig. 18 \& 19). Rays 3-4 per tangential mm. Tracheid pits to rays not observed. Oil cells and storied structure absent. Crystals not observed. Pith elliptic (partly crushed), composed of thin-walled parenchymatous cells (Fig. 6). 

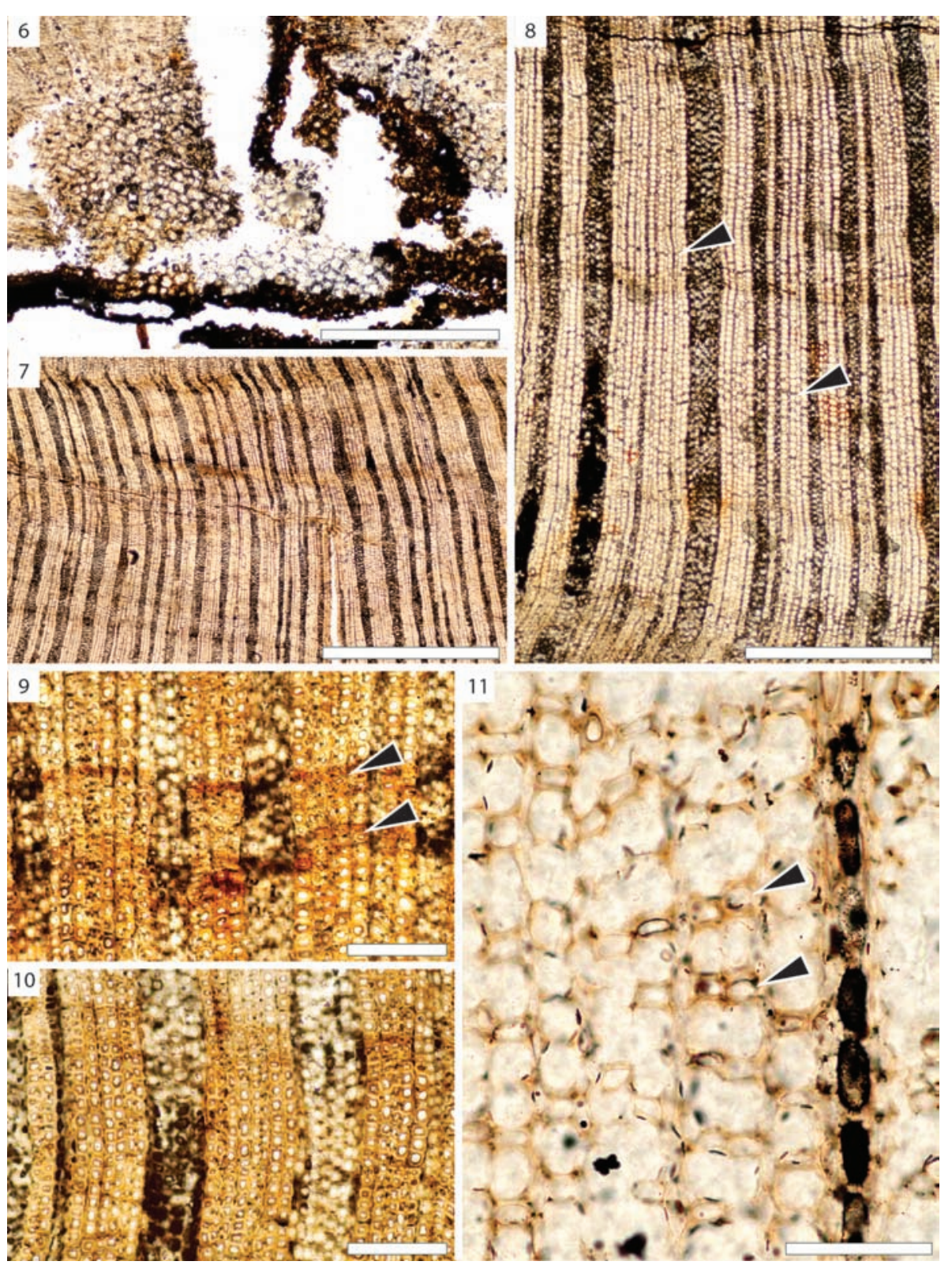

Figure 6-11. Transverse sections of Sherwinoxylon winteroides Boura \& Saulnier, sp.nov. 6: Parenchymatous pith, UP/SCF.17.007. - 7, 8: Homoxylous wood with broad rays, axial parenchyma diffuse-in-aggregates (arrowheads), UP/SCF.17.005. - 9, 10: Thick-walled tracheids; note the indistinct growth rings (arrowheads) marked by 1-3 rows of flattened tracheids with thickened walls, UP/SCF.17.004 - 11: Axial parenchyma diffuse-in-aggregates (arrowheads), UP/SCF.17.003. - Scale bar $6=1 \mathrm{~mm}, 7=2 \mathrm{~mm}, 8=500 \mu \mathrm{m}, 9 \& 10=250 \mu \mathrm{m}$, $11=100 \mu \mathrm{m}$. 

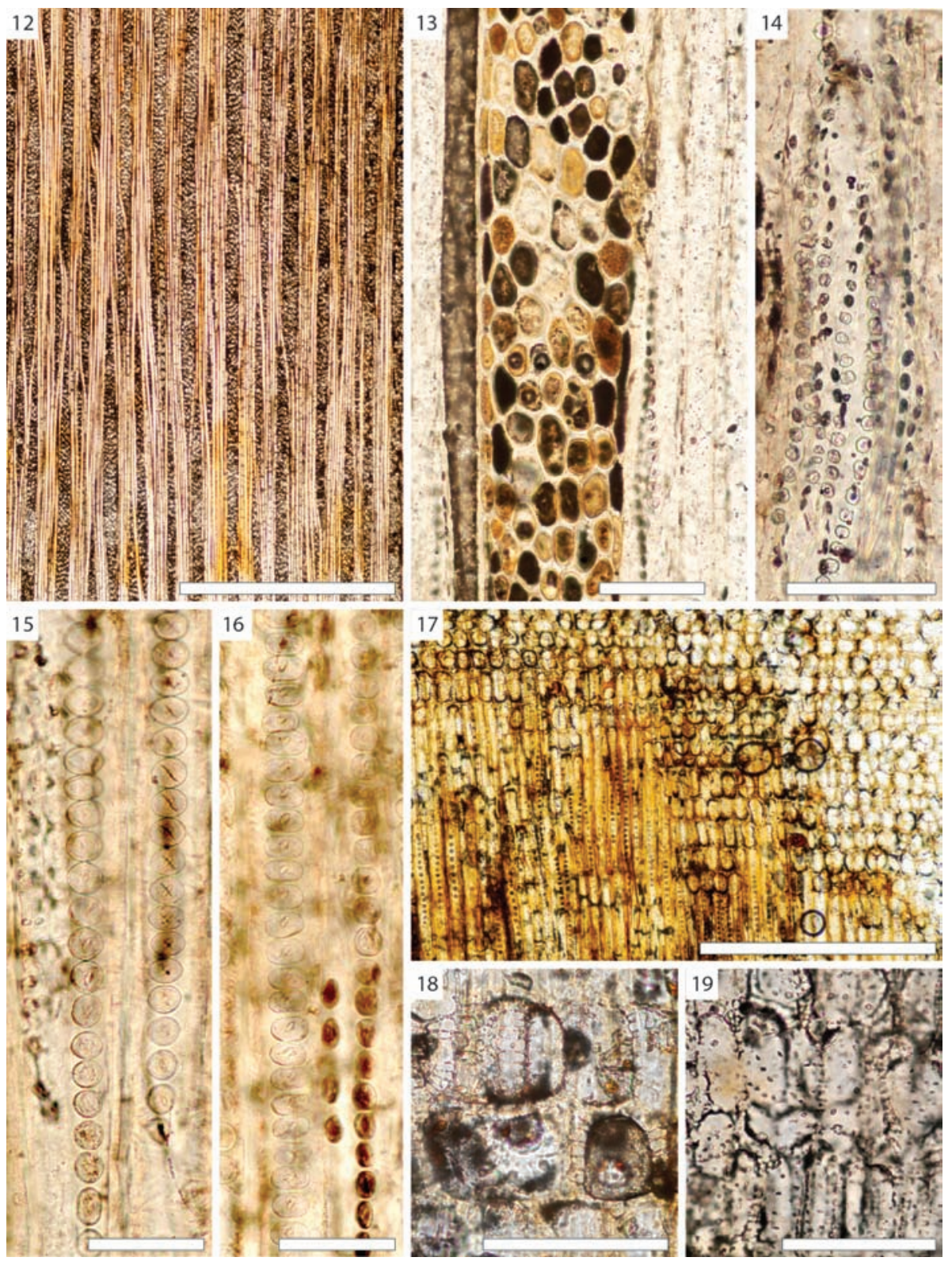

Figure 12-19. Longitudinal sections of Sherwinoxylon winteroides Boura \& Saulnier, sp.nov. 12 \& 13: TLS, exclusively multiseriate rays, UP/SCF.17.004 (12) \& UP/SCF.17.003 (13). 14: TLS, bordered pits in tangential walls of tracheids, UP/SCF.17.003. - 15 \& 16: RLS, circular to elliptical often contiguous bordered pits, UP/SCF.17.004. - 17: RLS, rays composed of square cells, with several rows of upright marginal cells, UP/SCF.17.006. - 18: RLS, thick-walled ray cells with simple to weakly bordered pits (funnel-shaped in section), UP/SCF.17.005 . - 19: RLS, ray cell pitting, UP/SCF.17.006. - Scale bar $12=2 \mathrm{~mm}, 17=500 \mu \mathrm{m}, 13=250 \mu \mathrm{m}, 14,18,19=$ $100 \mu \mathrm{m}, 15,16=50 \mu \mathrm{m}$. 


\section{Affinities}

The specimens described above are characterized by the rare combination of 1) homoxylous pycnoxylic wood with faint growth rings, 2) very broad (up to 9 cells wide) and high rays. Additionally they also show 3 ) exclusively circular to oval, often contiguous, bordered pits with oblique apertures, and 4) axial parenchyma diffuse to diffuse-in-aggregates and in short uniseriate bands.

Lack of vessels is one of the characteristic features of Coniferophyta. It also characterizes several other extant and fossil clades of both free-sporing or seed plants like Progymnosperms, Ginkgophyta, Pteridospermatophyta, Cycadophyta, Bennettitales and a few genera of angiosperms. Conifers, Ginkgophyta and Progymnosperms have almost exclusively short and uniseriate rays usually composed of radially rather than vertically elongated parenchyma cells (Bailey 1944; Greguss 1955). The ScorbéClairvaux specimens described here with rays composed of up to 9 cells wide differ from these three latter taxa. Cycadales and Bennettitales also show either one or a combination of several anatomical features that differ significantly from our specimens, like a large and well-developed pith with vascular bundles in the pith (Cycadales) associated with mucilage canals (Cycadales and Bennettitales); a narrow woody cylinder; a broad cortex; scalariform wall pitting of the secondary xylem sometimes with leaf traces; polyxyly (Cycadales) (Stevenson 1990; Jud et al. 2010).

A few Paleozoic fossil genera show a structure similar to that of the specimens described herein. The presence of a homoxylous wood with broad rays can be observed for instance in the species of the genus Pitys Witham. Philippe et al. (2010) and Sakala et al. (2018) pointed out that such a type of wood can be collected from more recent rocks due to the reworking during the burying process as this probably happened for the specimen attributed to Tetracentronites hungaricus Greguss. This explanation does not apply to the Scorbé-Clairvaux specimens. The fossil deposit is located on the southwestern edge of the Paris basin, and in this area the oldest rocks are posterior to Kimmeridgian. The green sandstones bearing the fossil wood specimens and the white sandstones of Vierzon, just below, lie on the lower Kimmeridgian yellow limestones. In addition, the specimens described here were collected with many other fossil wood specimens. They all have a homogeneous appearance. A preliminary analysis (Saulnier et al. 2018) proved that the plant assemblage was typically Cretaceous in age consisting of several specimens of Tempskya Corda, several conifer species (including one which belongs to Pinaceae) and several species of heteroxylous angiosperms. Furthermore, all Pitys species have multiseriate radial tracheid pits (between 3- and 5-seriate) (J.Galtier, pers. comm.), which is not the case in our specimens.

The combination of homoxylous wood and broad rays most probably indicates that the specimens described here belong to a vesselless angiosperm. The absence of vessels occurs in several genera and species of several families: Amborella Baill. in the Amborellaceae, all genera in the Winteraceae (Drimys J.R. Forst. \& G. Forst., Pseudowintera Dandy, Takhtajania M. Baranova \& J.-F. Leroy, Zygogynum Baill., Bubbia Tiegh., Exospermum Tiegh., Tasmannia R.Br. ex DC., Belliolum Tiegh.), Sarcandra in the Chloranthaceae, Trochodendron and Tetracentron in the Trochodendraceae (see Table 1 for a comparison of the anatomy of extant and fossil vessel- 
Table 1. Overview of extant and fossil vesselless angiosperm woods.

$\mathbf{E} / \mathbf{F}=$ Extant or Fossil, $\mathrm{E}=$ extant, $\mathrm{F}=$ fossil $-\mathbf{G R B}=$ Growth-ring boundaries,$+=$ present,$+/-=$ indistinct or absent,$-=$ absent, $\mathrm{v}=$ variable among species $-\mathbf{T T P}=$ Tracheid-tracheid pits, $\mathrm{r}=$ pits confined largely to radial walls, $\mathrm{t}=$ presence of pits commonly in tangential walls, $\mathrm{s}=$ scalariform, $(\mathrm{s})=$ rarely scalariform, $\mathrm{c}=$ circular,$(\mathrm{c})=$ rarely circular, $\mathrm{ew}=$ earlywood, $\mathrm{lw}=$ latewood, $\mathrm{v}=$ variable among species - TOEP $=$ Tracheid overlapping end pits, $\mathrm{s}=$ scalariform, $\mathrm{c}=$ circular, $(\mathrm{s})=$ rarely scalariform, $\mathrm{v}=$ variable among species $-\mathbf{P A R}=$ Axial parenchyma,$+=$ present,$-=$ rare or absent, $\mathrm{s}=$ scanty, $\mathrm{d}=$ diffuse, $\mathrm{d} \& \mathrm{a}=$ diffuse-in-aggregates, $\mathrm{m}=$ marginal bands, $\mathrm{b}=$ thin bands, top $=$ tangentially oriented pairs $-\mathbf{S T D} \mathbf{L}=\mathrm{Strand}$ length, $8+=$ over eight cells $-\mathbf{U R}=$ uniseriate rays,$+=$ present,$-=$ absent,$(1-2)=$ uniseriate or sometimes biseriate, $\mathrm{He}=$ heterocellular, Ho $=$ homocellular, $\mathrm{p}=$ all ray cells procumbent, $\mathrm{us}=$ all ray cells upright and/or square, $\mathrm{m}=$ rays with procumbent, square and upright cells mixed throughout the ray $-\mathbf{R W}=$ larger ray width $-\mathbf{R T}=$ larger ray type, $\mathrm{He}=$ heterocellular, $\mathrm{Ho}=$ homocelular, $\mathrm{p}=$ all ray cells procumbent, us $=$ all ray cells upright and/or square, $(\mathrm{p})=$ few files of procumbent cells present in wider rays, $\mathrm{m}=$ rays with procumbent, square and upright cells mixed throughout the ray, $(2-4$ us $) \mathrm{p}=$ body ray cells procumbent with mostly $2-4$ rows of upright and /or square marginal cells, $(4+\mathrm{us}) \mathrm{p}=$ body ray cells procumbent with over 4 rows of upright and/or square marginal cells $-\mathbf{S C}=$ Sheath cell, $+=$ present,$-=$ absent, $\mathrm{v}=$ variable $-\mathbf{O C}=$ Oil or mucilage cells, $+=$ present,$-=$ absent.

References: Mathiesen 1932 (1); Bailey \& Swamy 1948 (2); Swamy \& Bailey 1950 (3); Hergert \& Phinney 1954 (4); Bailey 1957 (5); Greguss 1963 (6); Page 1968 (7); Patel 1974 (8); Meylan \& Butterfield 1978 (9); Carlquist 1981 (10); Carlquist 1982 (11); Keating \& Bolza 1982 (12); Scott \& Wheeler 1982 (13); Carlquist 1983a (14); Carlquist 1983b (15); Carlquist 1987 (16); Carlquist 1988 (17); Carlquist 1989 (18); Crane et al. 1991 (19); Suzuki et al. 1991 (20); Carlquist 1992 (21); Gottwald 1992 (22); Nardi \& Edlmann 1992 (23); Carlquist 2000 (24); Richter \& Dallwitz 2000 (25); Poole \& Francis 2000 (26); Carlquist \& Schneider 2001 (27); Gasson et al. 2011 (28); Sakala et al. 2018 (29); this study (30).

\begin{tabular}{|c|c|c|c|c|c|c|c|c|c|c|c|c|c|c|}
\hline $\mathbf{E} / \mathbf{F}$ & Species & Locality $(\mathrm{F})$ & Horizon $(\mathrm{F})$ & Ref. & GRB & TTP & TOEP & PAR & STD L & UR & RW & RT & SC & OC \\
\hline $\mathrm{E}$ & $\begin{array}{l}\text { Amborella } \\
\text { trichopoda Baill. }\end{array}$ & & & $2,5,27$ & $+/-$ & $\begin{array}{l}\mathrm{r} \\
\mathrm{s}(\mathrm{ew}) \\
\mathrm{c}(\mathrm{lw})\end{array}$ & $\mathrm{s}$ & $\begin{array}{l}+ \\
\text { d }\end{array}$ & $5-8$ & $\begin{array}{l}+(1-2) \\
\text { Ho, us }\end{array}$ & (2) $3-5$ & $\begin{array}{l}\text { Ho, us } \\
\text { (p) }\end{array}$ & $\mathrm{v}$ & - \\
\hline E & $\begin{array}{l}\text { Sarcandra glabra } \\
\text { (Thunb.) Nakai }\end{array}$ & & & $2,16,21$ & + & $\begin{array}{l}\text { r } \\
\text { s (ew) } \\
\text { c (lw) }\end{array}$ & $\mathrm{c}$ & $\begin{array}{l}+ \\
\mathrm{v}(\mathrm{d}, \mathrm{s}) \\
\text { top }\end{array}$ & $?$ & $\begin{array}{l}+ \\
\text { Ho, us }\end{array}$ & $2-5(10)$ & Ho, us & $\mathrm{v}$ & - \\
\hline $\mathrm{E}$ & $\begin{array}{l}\text { Trochodendron } \\
\text { aralioides } \\
\text { Siebold \& Zucc. }\end{array}$ & & & 12,25 & + & $\begin{array}{l}\mathrm{r} \\
\mathrm{t} \\
\mathrm{s}\end{array}$ & $?$ & $\begin{array}{l}+ \\
\text { d \& a } \\
\text { top }\end{array}$ & $\begin{array}{l}3-6 \\
5-8\end{array}$ & $\begin{array}{l}+ \\
\text { Ho, us }\end{array}$ & $2-8(10)$ & $\begin{array}{l}\mathrm{He} \\
(2-4 \text { us) } \\
\mathrm{p}\end{array}$ & - & - \\
\hline E & $\begin{array}{l}\text { Tetracentron } \\
\text { sinense } \\
\text { Oliv. }\end{array}$ & & & 20,28 & + & $\begin{array}{l}\mathrm{r} \\
\mathrm{s}(\mathrm{ew}) \\
\mathrm{c}(\mathrm{lw})\end{array}$ & ? & $\begin{array}{l}+ \\
\mathrm{d}, \mathrm{d} \& \mathrm{a} \\
\text { rare top }\end{array}$ & $2-8$ & $\begin{array}{l}+ \\
\text { Ho, p }\end{array}$ & $4-10$ & $\begin{array}{l}\text { Ho } \\
\mathrm{p}\end{array}$ & $\mathrm{v}$ & - \\
\hline
\end{tabular}

(continued) 
(Table 1 continued)

\begin{tabular}{|c|c|c|c|c|c|c|c|c|c|c|c|c|c|c|}
\hline $\mathbf{E} / \mathbf{F}$ & Species & Locality $(\mathrm{F})$ & Horizon $(\mathrm{F})$ & Ref. & GRB & TTP & TOEP & PAR & STD L & UR & RW & RT & SC & OC \\
\hline F & $\begin{array}{l}\text { Tetracentron japon- } \\
\text { oxylon Suzuki, } \\
\text { Joshi \& Noshiro. }\end{array}$ & Japan & Mio. & 20 & + & $\begin{array}{l}\mathrm{r} \\
\mathrm{s}(\mathrm{ew}) \\
\mathrm{c}(\mathrm{lw})\end{array}$ & $?$ & $\begin{array}{l}+ \\
d\end{array}$ & $?$ & $\begin{array}{l}+ \\
\text { Ho, us }\end{array}$ & $2-4$ & $\begin{array}{l}\mathrm{He} \\
\text { (1-4 us) } \\
\mathrm{p}\end{array}$ & - & - \\
\hline $\mathrm{F}$ & $\begin{array}{l}\text { Tetracentronites } \\
\text { hartzi } \\
\text { Mathiesen }\end{array}$ & Greenland & Tert. & 1 & + & $\begin{array}{l}\mathrm{r} \\
\mathrm{s}(\mathrm{ew}) \\
\mathrm{c}(\mathrm{lw})\end{array}$ & $?$ & $\begin{array}{l}+ \\
d\end{array}$ & $?$ & $\begin{array}{l}+ \\
\text { Ho, us }\end{array}$ & $2-8$ & $\begin{array}{l}\mathrm{He} \\
(4+\mathrm{us}) \\
\mathrm{p}\end{array}$ & - & - \\
\hline F & $\begin{array}{l}\text { Tetracentronites } \\
\text { hungaricus } \\
\text { Greguss }\end{array}$ & Hungary & Mio. & 6,29 & $+/-$ & $\begin{array}{l}\mathrm{r} \\
\mathrm{c}\end{array}$ & $?$ & - & $?$ & $\begin{array}{l}+ \\
\mathrm{He}, \mathrm{m}\end{array}$ & $2(3)$ & $\begin{array}{l}\mathrm{He} \\
\mathrm{m}\end{array}$ & - & - \\
\hline F & $\begin{array}{l}\text { Tetracentronites } \\
\text { panochetri } \\
\text { Page }\end{array}$ & $\begin{array}{l}\text { California, } \\
\text { USA }\end{array}$ & $\begin{array}{l}\text { Up. } \\
\text { Cret. }\end{array}$ & 7 & + & $\begin{array}{l}\mathrm{r} \\
\mathrm{s} \\
\mathrm{c}\end{array}$ & $?$ & $\begin{array}{l}+ \\
\mathrm{s}\end{array}$ & $?$ & $\begin{array}{l}+ \\
\text { Ho, us }\end{array}$ & $2-8$ & $\begin{array}{l}\text { Ho } \\
\text { us }\end{array}$ & + & - \\
\hline F & $\begin{array}{l}\text { Trochodendron } \\
\text { beckii (Hergert \& } \\
\text { Phinney) Scott \& } \\
\text { Wheeler }\end{array}$ & $\begin{array}{l}\text { Oregon, } \\
\text { USA }\end{array}$ & $\begin{array}{l}\text { Eoc } \\
\text { Oli. }\end{array}$ & 4,13 & + & $\begin{array}{l}\mathrm{r} \\
\mathrm{s}(\mathrm{ew}) \\
\mathrm{c}(\mathrm{lw})\end{array}$ & $?$ & $\stackrel{+}{\mathrm{d}, \mathrm{d} \& \mathrm{a}}$ & $?$ & $\begin{array}{l}+ \\
\text { Ho, us }\end{array}$ & $2-10$ & $\begin{array}{l}\mathrm{He} \\
(4+\text { us }) \mathrm{p}\end{array}$ & - & - \\
\hline F & $\begin{array}{l}\text { Nordenskioldia } \\
\text { borealis } \text { (Heer) } \\
\text { Crane, Manchester } \\
\text { \& Dilcher }\end{array}$ & Spitsberg & Pal. & 19 & $?$ & $\mathrm{c}$ & $?$ & $\begin{array}{l}+ \\
d \& a\end{array}$ & $?$ & $\begin{array}{l}+ \\
\text { Ho, us }\end{array}$ & - & - & - & - \\
\hline E & $\begin{array}{l}\text { Takhtajania } \\
\text { perrieri (Capuron) } \\
\text { M. Baranova \& } \\
\text { J.-F. Leroy }\end{array}$ & & & 24 & - & $\begin{array}{l}\mathrm{r} \\
\mathrm{c}, \mathrm{s}\end{array}$ & $\mathrm{c}, \mathrm{s}$ & $\begin{array}{l}+ \\
s, d\end{array}$ & $5-6$ & $\begin{array}{l}+ \\
\text { Ho, us }\end{array}$ & $2-5$ & $\begin{array}{l}\text { Ho, us } \\
\text { (p) }\end{array}$ & - & - \\
\hline E & $\begin{array}{l}\text { Tasmannia } \text { R. Br. ex } \\
\text { DC., } 14 \text { species }\end{array}$ & & & 18 & $\begin{array}{l}\mathrm{v} \\
(-,+/-)\end{array}$ & $\begin{array}{l}\mathrm{r} \\
\mathrm{c},(\mathrm{s})\end{array}$ & $\mathrm{c},(\mathrm{s})$ & $\begin{array}{l}\mathrm{v} \\
(-,+, \mathrm{d}, \mathrm{s})\end{array}$ & $?$ & $\begin{array}{l}+ \\
\text { Ho, us }\end{array}$ & $2-5(10)$ & $\begin{array}{l}\text { Ho, us } \\
\text { (p) }\end{array}$ & - & - \\
\hline E & $\begin{array}{l}\text { Zygogynum Baill. } \\
6 \text { species }\end{array}$ & & & 10 & $+/-$ & $\mathrm{v}(\mathrm{c}, \mathrm{s})$ & $\mathrm{v}(\mathrm{c}, \mathrm{s})$ & $\begin{array}{l}\mathrm{v}(+, \mathrm{s}, \mathrm{d}, \\
\mathrm{d} \& \mathrm{a}, \mathrm{b})\end{array}$ & $5-8+$ & $\begin{array}{l}+ \\
\mathrm{He}, \mathrm{m}\end{array}$ & $4-10$ & $\begin{array}{l}\mathrm{He} \\
(4+\mathrm{us}) \mathrm{p}\end{array}$ & + & + \\
\hline
\end{tabular}


(Table 1 continued)

\begin{tabular}{|c|c|c|c|c|c|c|c|c|c|c|c|c|c|c|}
\hline$E / F$ & Species & Locality (F) & Horizon $(\mathrm{F})$ & Ref. & GRB & TTP & TOEP & PAR & STD L & UR & RW & RT & SC & OC \\
\hline E & $\begin{array}{l}\text { Drimys J.R.Forst. } \\
\text { ex G.Forst. } \\
7 \text { species }\end{array}$ & & & $\begin{array}{l}14,17, \\
23\end{array}$ & $\begin{array}{l}\mathrm{v}(+/-, \\
+,-)\end{array}$ & $\begin{array}{l}\mathrm{r}, \mathrm{c},(\mathrm{s}) \\
\text { (ew) }\end{array}$ & $\begin{array}{l}\mathrm{c} \\
\mathrm{c}(\mathrm{lw})\end{array}$ & $\stackrel{+}{\mathrm{d}, \mathrm{d} \& \mathrm{a}}$ & $?$ & $\begin{array}{l}+ \\
\text { Ho, us }\end{array}$ & $2-10$ & $\begin{array}{l}\mathrm{He} \\
(4+\text { us }) \mathrm{p}\end{array}$ & - & - \\
\hline E & $\begin{array}{l}\text { Pseudowintera } \\
\text { Dandy, } 3 \text { species }\end{array}$ & & & 8,9 & $\begin{array}{l}\mathrm{v}(+/-, \\
+)\end{array}$ & $\begin{array}{l}\mathrm{r} \\
\mathrm{c}\end{array}$ & $?$ & $\begin{array}{l}\mathrm{d}, \mathrm{d} \& \mathrm{a}, \\
\mathrm{m}\end{array}$ & $2-12$ & $\stackrel{+}{\text { Ho, us }}$ & $7-29$ & $\begin{array}{l}\mathrm{He} \\
(4+\text { us }) \mathrm{p}\end{array}$ & $\mathrm{v}$ & - \\
\hline E & $\begin{array}{l}\text { Bubbia Tiegh. } \\
\text { ? }\end{array}$ & & & 10,15 & $\mathrm{v}(-,+/-)$ & $\mathrm{v}(\mathrm{c}, \mathrm{s})$ & $\mathrm{v}(\mathrm{c}, \mathrm{s})$ & $\mathrm{v}(+, \mathrm{d}, \mathrm{b})$ & $2-8$ & $\begin{array}{l}+ \\
\text { Ho, us }\end{array}$ & $4-10$ & $\begin{array}{l}\mathrm{He} \\
(1-4 \mathrm{us}) \mathrm{p}\end{array}$ & $\mathrm{v}$ & + \\
\hline E & $\begin{array}{l}\text { Exospermum } \\
\text { stipitatum (Baill.) } \\
\text { Tiegh. (unresolved } \\
\text { according to plant } \\
\text { list }\end{array}$ & & & 11 & - & $\mathrm{c}$ & $\mathrm{c}$ & $\begin{array}{l}+ \\
\mathrm{d}, \mathrm{b}\end{array}$ & $5-8+$ & $\begin{array}{l}+ \\
\text { Ho, us }\end{array}$ & $4-10$ & $\begin{array}{l}\mathrm{He} \\
(4+\mathrm{us}) \mathrm{p}\end{array}$ & $\mathrm{v}$ & + \\
\hline F & $\begin{array}{l}\text { Winteroxylon } \\
\text { mundlosi } \\
\text { Gottwald }\end{array}$ & Europe & Eoc. & 22 & $+/-$ & $\mathrm{c}, \mathrm{s}$ & $?$ & $\begin{array}{l}+ \\
b\end{array}$ & $?$ & + & $3-7$ & $\begin{array}{l}\mathrm{He} \\
(1-4 u s) \mathrm{p}\end{array}$ & - & + \\
\hline F & $\begin{array}{l}\text { Winteroxylon } \\
\text { jamesrossi } \\
\text { Poole \& Francis }\end{array}$ & Antarctica & $\begin{array}{l}\text { Up. } \\
\text { Cret. }\end{array}$ & 26 & $+/-$ & $\begin{array}{l}\mathrm{r} \\
\mathrm{c}, \mathrm{s}\end{array}$ & $\mathrm{s}$ & $\begin{array}{l}+ \\
\mathrm{d}, \mathrm{d} \& \mathrm{a}\end{array}$ & $?$ & $\begin{array}{l}+ \\
\text { Ho, us }\end{array}$ & $4-13$ & $\begin{array}{l}\mathrm{He} \\
\mathrm{m}\end{array}$ & + & - \\
\hline $\mathbf{F}$ & $\begin{array}{l}\text { Sherwinoxylon } \\
\text { winteroides } \\
\text { gen. nov., sp. nov. }\end{array}$ & Europe & Cen. & 30 & $+/-$ & $\begin{array}{l}\mathbf{r} \\
\mathbf{c}\end{array}$ & c & $\begin{array}{l}+ \\
\text { d, d\&a }\end{array}$ & $8+$ & - & 4-9 & $\begin{array}{l}\text { Ho } \\
\text { us }\end{array}$ & - & - \\
\hline
\end{tabular}


less angiosperms). Amborella trichopoda has predominantly uniseriate rays and scalariform end walls in earlywood tracheids. Both Tetracentron and Trochodendron in the Trochodendraceae and Sarcandra in the Chloranthaceae are characterized by well-marked growth-ring boundaries and scalarifom tracheid-tracheid pits at least in earlywood, tangentially oriented pairs of axial parenchyma strands deriving from a single fusiform cambial initial (rare in Tetracentron) (Bailey 1944; Swamy \& Bailey 1950; Carlquist 1983b; Table 1). Numerous characteristics of the specimens described here are present in the genera of Winteraceae (Table 1) like 1) indistinct growth rings (Tasmannia, Zygogynum, Pseudowintera, Bubbia); 2) bordered pits circular or slightly elongated (Pseudowintera, Exospermum); 3) axial parenchyma diffuse in aggregates (Zygogynum, Drimys, Pseudowintera, Bubbia), 4) long parenchyma strands often of up to 8 cells (Zygogynum, Pseudowintera, Exospermum) and 5) Presence of numerous and small pits in the ray cell walls (Bubbia, Drimys, Zygogynum, Pseudowintera). Nevertheless, all these genera differ from the Scorbé-Clairvaux specimens because 1) they show both uniseriate and multiseriate rays, 2) tracheid pits are largely confined to radial walls. Yet we consider it likely that the specimens studied here belong to the Winteraceae, despite the differences mentioned above. It is difficult to attribute those specimens to any of the extant genera. The specimens share several characters of the Winteraceae (in the crown group [Zygogynum - Bubbia - Pseudowintera - Drimys] or in its sister group, the genus Tasmannia); (for phylogeny and distribution of vesselless wood, see Doust and Drinnan (2004), Feild et al. (2002), and Thomas et al. (2014).

Several fossil genera have been erected for the fossil woods of homoxylous angiosperms: Nordenskioldia Heer for twigs associated with fruits and leaves of this same genus (Trochodendraceae), Tetracentronites Mathiesen (Trochodendraceae), Winteroxylon Gottwald (Winteraceae). Also several fossil woods were attributed to extant Tetracentron and Trochodendron, like Tetracentron japonoxylum Suzuki, Joshi \& Noshiro and Trochodendron beckii (Hergert \& Phinney) Scott \& Wheeler (syn. Trochodendroxylon beckii Hergert \& Phinney), when the fossil specimens closely resembled and were only comparable to a single living genus. As observed in living species of Trochodendraceae, the fossil specimens attributed to Trochodendroxylon and Tetracentronites must have, based on their diagnoses, distinct growth-ring boundaries, scalariform pits at least at the end of the tracheids and two distinct types of rays, uniseriate and multiseriate. The genera Homoxylon Hartig, Sahnioxylon Bose \& Sah and Pataloxylon Sahni were also sometimes used for homoxylous angiosperms but they most probably represent conifers, bennettites or even heteroxylous angiosperms (for a review see Suzuki et al. 1991). Several specimens were transferred to Sahnioxylon Bose \& Sah and Phoroxylon Sze, which are now considered to be Bennettitales or Cycadales (Suzuki et al. 1991; Gregory et al. 2009). Winteroxylon was erected by Gottwald (1992) and later emended by Poole and Francis (2000) for vesselless angiosperms with indistinct growth rings, circular pits, apotracheal parenchyma diffuse or in short uniseriate bands and presence of both uniseriate and multiseriate rays (among other features). Two species of Winteroxylon were already described: the first, W. mundlosi Gottwald from the upper Eocene of Europe, the second from the Upper Cretaceous of Antarctica, $W$. jamesrossi Poole \& Francis. The absence of uniseriate rays makes Sherwinoxylon 
quite unique among vesselless angiosperms in general and Winteraceae in particular. The fossils show some similarities with extant Winteraceae and Winteroxylon, but due to the absence of uniseriate rays, we consider it prudent and justified to erect a new genus of vesselless fossil angiosperm wood. As stated by Doyle (2000), when discussing the affinities of Winteroxylon mundlosi, other vesselless angiosperm lineages that resemble Winteraceae, but are unrelated, may have existed in the past. In view of its singularities, our specimens may belong to such an extinct group, either unrelated to Winteraceae or placed at the base of the main clade of the Winteraceae. The splitting between those clades has been dated around $91 \mathrm{Ma}$ (Thomas et al. 2014), which is consistent with the age of the locality.

\section{ACKNOWLEDGMENTS}

This work is supported in part by the Lisea Fondation Biodiversité (research grant 97 to the Palaios association with the project 'Past of Biodiversity from Vienne'). GG and XV acknowledge the Lisea Society (L. Dauchet, M. Lafaurie, L. Cavois and H. Le Caignec) for support assistance, the municipalities of Colombiers and Scorbé-Clairvaux (J. Gauthier, L. Juge and A. Vausselle), and the Society of Bourdilleau for technical support. We want to warmly thank Vincent Rommevaux (CR2P, CNRS) for the thin sections preparation. We thank Pieter Baas and Elisabeth Wheeler for the invitation to submit the article to the IAWA Journal. We are also grateful to Pieter Baas, Jakub Sakala and one anonymous reviewer for their comments on the early version of this article which contributed to significantly improve it.

\section{REFERENCES}

Angiosperm Phylogeny Group (APG). 2016. An update of the Angiosperm Phylogeny Group classification for the orders and families of flowering plants: APG IV. Bot. J. Linn. Soc. 181: 1-20. https://doi.org/10.1111/boj.12385.

Azéma C, Durand S, Médus J. 1972. Des miospores du Cénomanien moyen. Paléobiologie continentale 3 (4): 1-54.

Baas P, Wheeler EA. 1996. Parallelism and reversibility in xylem evolution - a review. IAWA J. 17: 351-364. DOI: 10.1163/22941932-90000633.

Bailey IW. 1944. The comparative morphology of the Winteraceae: III. Wood. J. Arnold Arbor. 25: 97-103.

Bailey IW. 1957. Additional notes on the vesselless dicotyledon, Amborella trichopoda Baill. J. Arnold Arbor. 38: 374-380.

Bailey IW, Swamy BGL. 1948. Amborella trichopoda Baill., a new morphological type of vesselless dicotyledon. J. Arnold Arbor. 29: 245-254.

Bourgueil B, Cariou E, Moreau P, Ducloux J. 1976. Carte géologique de la France au 1/50 000. Vouneuil-sur-Vienne. XVIII-26. BRGM, Orléans.

Carlquist S. 1975. Ecological strategies of xylem evolution. University of California Press, Berkeley.

Carlquist S. 1981. Wood anatomy of Zygogynum (Winteraceae); field observations. Bull. Mus. Natl. Hist. Nat. 3: 281-92.

Carlquist S. 1982. Exospermum stipitatum (Winteraceae): observations on wood, leaves, flowers, pollen, and fruit. Aliso 10: 277-289.

Carlquist S. 1983a. Wood anatomy of Belliolum (Winteraceae) and a note on flowering. J. Arnold Arbor. 64: 161-169. 
Carlquist S. 1983b. Wood anatomy of Bubbia (Winteraceae), with comments on origin of vessels in dicotyledons. Am. J. Bot. 70: 578-590. DOI: 10.2307/2443169.

Carlquist S. 1987. Presence of vessels in wood of Sarcandra (Chloranthaceae); comments on vessel origins in angiosperms. Am. J. Bot. 74: 1765-1771. DOI: 10.2307/2443959.

Carlquist S. 1988. Wood anatomy of Drimys s.s. (Winteraceae). Aliso 12: 81-95.

Carlquist S. 1989. Wood anatomy of Tasmannia. Aliso 12: 257-275.

Carlquist S. 1992. Wood anatomy and stem of Chloranthus; summary of wood anatomy of Chloranthaceae, with comments on relationships, vessellessness, and the origin of monocotyledons. IAWA J. 13: 3-16. https://doi.org/10.1163/22941932-90000556.

Carlquist S. 2000. Wood and bark anatomy of Takhtajania (Winteraceae); phylogenetic and ecological implications. Ann. Mo. Bot. Gard. 87: 317-322. DOI: 10.2307/2666191.

Carlquist S. 2001. Comparative wood anatomy. Systematic, ecological, and evolutionary aspects of dicotyledon wood. Ed. 2. Springer-Verlag, Berlin.

Carlquist S, Schneider EL. 2001. Vegetative anatomy of the New Caledonian endemic Amborella trichopoda: relationships with the Illiciales and implications for vessel origin. Pac. Sci. 55: 305-312.

Carlquist S, Schneider EL. 2002. The tracheid-vessel element transition in angiosperms involves multiple independent features: cladistic consequences. Am. J. Bot. 89: 185-195. DOI: 10.3732/ajb.89.2.185.

Chaney RW, Sanborn EI. 1933. The Goshen flora of west central Oregon. Carnegie Institution of Washington Publication, Washington.

Chase MW, Soltis DE, Olmstead RG, Morgan D, Les DH, Mishler BD, Duvall MR, Price RA, Hills HG, Qiu YL, Kron KA, Rettig JH, Conti E, Palmer JD, Manhart JR, Sytsma KJ, Michael HJ, Kress WJ, Karol KA, Clark WD, Hedrén M, Gaut BS, Jansen RK, Kim KJ, Wimpee CF, Smith JF, Furnier GR, Strauss SH, Xiang QY, Plunkett GM, Soltis PS, Swensen SM, Williams SE, Gadek PA, Quinn CJ, Eguiarte LE, Golenberg E, Learn GH, Graham SW Jr, Barrett SCH, Dayanandan S, Albert VA. 1993. Phylogenetics of seed plants: an analysis of nucleotide sequences from the plastid gene rbcL. Ann. Mo. Bot. Gard. 80: 528-580. DOI: 10.2307/2399846.

Christenhusz MJ, Fay MF, Chase MW. 2017. Plants of the world: An illustrated encyclopedia of vascular plants. University of Chicago Press, Chicago.

Crane PR, Manchester SR, Dilcher DL. 1991. Reproductive and vegetative structure of Nordenskioldia (Trochodendraceae), a vesselless dicotyledon from the early Tertiary of the Northern Hemisphere. Am. J. Bot. 78: 1311-1334. DOI: 10.2307/2445271.

Crié L. 1884. Contribution à l'étude de la flore crétacée de l'Ouest de la France. C.R. Acad. Sci. Paris 99: 511-513.

Dettmann ME, Jarzen DM. 1990. The Antarctic/Australian rift valley: Late Cretaceous cradle of northeastern Australasian relicts? Rev. Palaeobot. Palynol. 65: 131-144. https://doi.org/ 10.1016/0034-6667(90)90064-P.

Doust AN, Drinnan AN. 2004. Floral development and molecular phylogeny support the generic status of Tasmannia (Winteraceae). Am. J. Bot. 91: 321-331. DOI: 10.3732/ajb.91.3.321.

Doyle JA. 2000. Paleobotany, relationships, and geographic history of Winteraceae. Ann. Mo. Bot. Gard. 87: 303-316. DOI: 10.2307/2666190.

Doyle JA, Endress PK. 2014. Integrating Early Cretaceous fossils into the phylogeny of living angiosperms: ANITA lines and relatives of Chloranthaceae. Int. J. Plant Sci. 175: 555-600. https://doi.org/10.1086/675935.

Doyle JA, Hotton CL, Ward JV. 1990. Early Cretaceous tetrads, zonasulcate pollen, and Winteraceae. I. Taxonomy, morphology, and ultrastructure. Am. J. Bot. 77, 1544-1557. DOI: $10.2307 / 2444487$. 
Eklund H, Doyle JA, Herendeen PS. 2004. Morphological phylogenetic analysis of living and fossil Chloranthaceae. Int. J. Plant Sci. 165: 107-151. DOI: 10.1086/380987.

Endress PK. 1986. Floral structure, systematics, and phylogeny in Trochodendrales. Ann. Mo. Bot. Gard. 73: 297-324. DOI: 10.2307/2399115.

Feild TS, Brodribb T, Holbrook NM. 2002. Hardly a relict: freezing and the evolution of vesselless wood in Winteraceae. Evolution 56: 464-478. https://doi.org/10.1111/j.0014-3820. 2002.tb01359.x.

Feild TS, Zwieniecki MA, Brodribb T, Jaffré T, Donoghue MJ, Holbrook NM. 2000. Structure and function of tracheary elements in Amborella trichopoda. Int. J. Plant Sci. 161: 705-712. DOI: $10.1086 / 314293$.

Fleury R, Polette F, Batten DJ, Durand M, Moreau JD, Néraudeau D, Strullu-Derrien C, Redois F. 2017. Palaeobotanical investigation of a Cenomanian clay lens in Hucheloup Quarry, Maine-et-Loire, NW France: Taxonomic, stratigraphic and palaeoenvironmental implications. Ann. Paleontol. 103: 235-250. DOI: 10.1016/j.annpal.2017.10.003.

Friis EM, Crane PR, Pedersen KR. 2011. Early flowers and angiosperm evolution. Cambridge University Press, Cambridge.

Friis EM, Pedersen KR, Crane PR. 1994. Angiosperm floral structures from the Early Cretaceous of Portugal. Plant Syst. Evol. Suppl. 8: 31-49. https://doi.org/10.1007/978-3-70916910-0_3.

Gabilly J, Cariou E. 1997. Poitou, Vendée, Charentes. Guides géologiques régionaux. Ed. 2. Masson, Paris.

Gasson P, Baas P, Wheeler E. 2011. Wood anatomy of CITES-listed tree species. IAWA J. 32: 155-198. DOI: 10.1163/22941932-90000050.

Gomez B, Coiffard C, Dépré E, Daviero-Gomez V, Néraudeau D. 2008. Diversity and histology of a plant litter bed from the Cenomanian of Archingeay-Les Nouillers (southwestern France). C. R. Palevol. 7: 135-144. DOI: 10.1016/j.crpv.2007.12.006.

Gomez B, Daviero-Gomez V, Garcia G, Caner L, Boura A, Barral A, Cantinolle P, Valentin X. 2018. Silicified plant megafossils from the upper Turonian of Vienne, western France. Earth Environ. Sci. Trans. R. Soc. Edinb. 108: 449-457. DOI: 10.1017/S1755691018000105.

Gomez B, Daviero-Gomez V, Perrichot V, Thévenard F, Coiffard C, Philippe M, Néraudeau D. 2004. Assemblages floristiques de l'Albien-Cénomanien de Charente-Maritime (SO France). Ann. Paleontol. 90: 147-159. DOI: 10.1016/j.annpal.2004.03.003.

Gottwald H. 1992. Hölzer aus marinen Sanden des oberen Eozän von Helmstedt (Niedersachsen). Palaeontographica B 225: 27-103.

Gregory M, Poole I, Wheeler EA. 2009. Fossil dicot wood names: an annotated list with full bibliography. IAWA Journal Supplement 6, $220 \mathrm{pp}$.

Greguss P. 1955. Identification of living gymnosperms on the basis of xylotomy. Akadémiai Kiado, Budapest.

Greguss P. 1963. A new homoxylous tree Tetracentronites hungaricum n. sp. The Palaeobotanist 12: 1-10.

Grímsson F, Grimm GW, Potts AJ, Zetter R, Renner SS. 2018. A Winteraceae pollen tetrad from the early Paleocene of western Greenland, and the fossil record of Winteraceae in Laurasia and Gondwana. J. Biogeogr. 45: 567-581. DOI: 10.1111/jbi.13154.

Grímsson F, Xafis A, Neumann FH, Zetter R. 2017. Pollen morphology of extant Winteraceae: a study allowing SEM-based affiliation of its fossil representatives. Acta Palaeobot. 57: 339-396. DOI: 10.1515/acpa-2017-0015.

Hergert HL, Phinney HK. 1954. Trochodendroxylon beckii gen. et sp. nov. from the Tertiary of Oregon. Bull. Torrey Bot. Club 81: 118-122. DOI: 10.2307/2481846. 
Hufford L, Crane PR. 1989. A preliminary phylogenetic analysis of the "lower" Hamamelidae. In: Crane PR, Blackmore S (eds.), Evolution, systematics and fossil history of the Hamamelidae, Vol. 1: 175-192. Clarendon Press, Oxford.

IAWA Committee. 1989. IAWA List of microscopic features for hardwood identification. IAWA Bull.n.s. 10: 219-332.

InsideWood. 2004-onwards. Published on the Internet. http://insidewood.lib.ncsu.edu/search [October 2018].

Jones TP, Rowe NP. 1999. Fossil plants and spores: modern techniques. Geol. Soc., London.

Jud NA, Rothwell GW, Stockey RA. 2010. Paleoecological and phylogenetic implications of Saxicaulis meckertii gen. et sp. nov.: a bennettitalean stem from the Upper Cretaceous of western North America. Int. J. Plant Sci. 171: 915-925. DOI: 10.1086/655963.

Juignet P, Médus J. 1971. Les argiles noires d'Écommoy (Sarthe): Précisions sédimentologiques et palynologiques. Bull. Soc. géol. Fr. 6: 310-312.

Keating WG, Bolza E. 1982. Characteristics, properties, and uses of timbers. Vol. I. Southeast Asia, Northern Australia and the Pacific. Texas A\&M University Press.

Laing JF. 1975. Mid-Cretaceous angiosperm pollen from southern England and northern France. Palaeontol. 18: 775-808.

Li HF, Chaw SM, Du CM, Ren Y. 2011. Vessel elements present in the secondary xylem of Trochodendron and Tetracentron (Trochodendraceae). Flora. 206: 595-600. https://doi. org/10.1016/j.flora.2010.11.018.

Mathiesen J. 1932. Notes on some fossil plants from East Greenland. Medd. Grønl. 85: 1-62.

Médioni R, Debrand-Passard S, Perna G, Weecksteen M. 1974. Carte géologique au 1/50 000. Châtellerault. XVIII-25. BRGM, Orléans.

Metcalfe CR, Chalk L. 1950. Anatomy of the Dicotyledons. The Clarendon Press, Oxford.

Metcalfe CR, Chalk L. 1987. Anatomy of the Dicotyledons, Second Edition, Volume 3. Oxford Scientific Publications.

Meylan BA, Butterfield BG. 1978. The structure of New Zealand woods. NZ Dept. Sci. Ind. Res. Bull. 222.

Mildenhall DC, Crosbie YM. 1979. Some porate pollen from the upper Tertiary of New Zealand. New Zeal. J. Geol. Geop. 22: 499-508. DOI: 10.1080/00288306.1979.10424159.

Nardi R, Edlmann A. 1992. Legnami tropicali importati in Italia: anatomia e identificazione. Vol. II. América Latina. Istituto di Assestamento e Tecnología Forestale, Firenze.

Néraudeau D, Allain R, Perrichot V, Videt B, De Broin F, Guillocheau F, Philippe M, Rage JC, Vullo R. 2003. Découverte d'un dépôt paralique à bois fossiles, ambre insectifère et restes d'Iguanodontidae (Dinosauria, Ornithopoda) dans le Cénomanien inférieur de Fouras (Charente-Maritime, sud-ouest de la France).C.R. Palevol. 2: 221-230. DOI: 10.1016/ S1631-0683(03)00032-0.

Néraudeau D, Perrichot V, Batten DJ, Boura A, Girard V, Jeanneau L, Nohra YA, Polette F, Saint Martin S, Saint Martin JP, Thomas R. 2017. Upper Cretaceous amber from Vendée, north-western France: age dating and geological, chemical, and palaeontological characteristics. Cretac. Res. 70: 77-95. https://doi.org/10.1016/j.cretres.2016.10.001.

Néraudeau D, Perrichot V, Colin JP, Girard V, Gomez B, Guillocheau F, Masure E, Peyrot D, Tostain F, Videt B, Vullo R. 2008. A new amber deposit from the Cretaceous (uppermost Albian-lowermost Cenomanian) of southwestern France. Cretac. Res. 29: 925-929. https://doi.org/10.1016/j.cretres.2008.05.009.

Néraudeau D, Redois F, Ballèvre M, Duplessis B, Girard V, Gomez B, Daviero-Gomez V, Melliere B, Perrichot V. 2013. L'ambre cénomanien d'Anjou: stratigraphie et paléontologie des carrières du Brouillard et de Hucheloup (Ecouflant, Maine-et-Loire). Ann. Paleontol. 99: 361-374. https://doi.org/10.1016/j.annpal.2013.10.001. 
Néraudeau D, Vullo R, Gomez B, Perrichot V, Videt B. 2005. Stratigraphie et paléontologie (plantes, vertébrés) de la série paralique Albien terminal-Cénomanien basal de TonnayCharente (Charente-Maritime, France). C. R. Palevol. 4: 79-93. https://doi.org/10.1016/ j.crpv.2004.11.008.

Page VM. 1968. Angiosperm wood from the Upper Cretaceous of Central California: Part II. Am. J. Bot. 55: 168-172. https://doi.org/10.1002/j.1537-2197.1968.tb06957.x.

Page VM. 1970. Angiosperm wood from the Upper Cretaceous of central California: III. Am. J. Bot. 57: 1139-1144. https://www.jstor.org/stable/2441279.

Patel RN. 1974. Wood anatomy of the dicotyledons indigenous to New Zealand 4. Wintera -ceae. N.Z. J. Bot. 12: 19-32. https://doi.org/10.1080/0028825X.1973.10430261.

Peyrot D, Jolly D, Barrón E. 2005. Apport de données palynologiques à la reconstruction paléoenvironnementale de l'Albo-Cénomanien des Charentes (Sud-Ouest de la France).C.R. Palevol. 4: 151-165. DOI : 10.1016/j.crpv.2004.11.016.

Philippe M, Cuny G, Bashforth A. 2010. Ecpagloxylon mathiesenii gen. nov. et sp. nov., a Jurassic wood from Greenland with several primitive angiosperm features. Plant Syst. Evol. 287: 153-165. DOI 10.1007/s00606-010-0308-z.

Pons D, Lauverjat J, Broutin J. 1980. Paléoclimatologie comparée de deux gisements du Crétacé supérieur d'Europe occidentale. Mém. Soc. géol. Fr. 139: 151-158.

Poole I, Francis JE. 2000. The first record of fossil wood of Winteraceae from the Upper Cretaceous of Antarctica. Ann. Bot. 85: 307-315. https://doi.org/10.1006/anbo.1999.1049.

Ren Y, Chen L, Tian XH, Zhang XH, Lu AM. 2007. Discovery of vessels in Tetracentron (Trochodendraceae) and its systematic significance. Pl. Syst. Evol. 267: 155-161. https:// doi.org/10.1007/s00606-007-0563-9.

Richter HG, Dallwitz MJ. 2000-onwards. Commercial timbers: descriptions, illustrations, identification, and information retrieval. Version: 25th June 2009.

Robin N, Velasquez M, Boura A, Garcia G, Jauvion C, Boiteau JM, Gomez B, DavieroGomez V, Valentin X. 2018. The oldest shipworms (Bivalvia, Pholadoidea, Teredinidae) preserved with soft parts (western France): insights into the fossil record and evolution of Pholadoidea. Palaeontol. 61: 905-918. https://doi.org/10.1111/pala.12376.

Sakala J, Selmeczi I, Hably L. 2018. Reappraisal of Greguss' fossil wood types and figured specimens from the Cenozoic of Hungary: Overview, corrected geology and systematical notes. Fossil Imprint 74: 101-114. DOI: 10.2478/if-2018-0008.

Saulnier G, Boura A, Bernard G, Daviero-Gomez V, De Franceschi D, Pons D, Garcia G, Boiteau J-M, Valentin X. 2018. Diversity in Cenomanian forests: an example from the Envigne Valley (Vienne), France. 10 ${ }^{\text {th }}$ European Palaeobotany and Palynology Conference, Dublin.

Schrank E. 2013. New taxa of winteraceous pollen from the Lower Cretaceous of Israel. Rev. Pal. Pal. 195: 19-25. http://dx.doi.org/10.1016/j.revpalbo.2013.03.005.

Scott RA, Wheeler EA. 1982. Fossil woods from the Eocene Clarno Formation of Oregon. IAWA J. 3: 135-154. https://doi.org/10.1163/22941932-90000829.

Stevenson DW. 1990. Morphology and systematics of the Cycadales. Mem. New York Bot. Gard. 57: 8-55. http://dx.doi.org/10.21135/893273507.003.

Stover LE, Partridge AD. 1973. Tertiary and Late Cretaceous spores and pollen from the Gippsland Basin, southeastern Australia. Proc. R. Soc. Victoria. 85: 237-286.

Suzuki M, Joshi L, Noshiro S. 1991. Tetracentron wood from the Miocene of Noto Peninsula, Central Japan, with a short revision of homoxylic fossil woods. Bot. Mag. (Tokyo) 104: 37-48. DOI: 10.1007/BF02493402.

Swamy BGL, Bailey IW. 1950. Sarcandra, a vesselless genus of the Chloranthaceae. J. Arnold Arbor. 31: 117-129. https://www.jstor.org/stable/43781355. 
Takahashi M, Herendeen PS, Xiao X. 2017. Two early eudicot fossil flowers from the Kamikitaba assemblage (Coniacian, Late Cretaceous) in northeastern Japan. J. Plant. Res. 130: 809-826. DOI: 10.1007/s10265-017-0945-1.

Tanaka S. 2008. Early Cretaceous angiosperm pollen fossils from Hokkaido, northern Japan. Terra Nostra 2: 276-277.

The Plant List. 2013. Version 1.1. Published on the Internet; http://www.theplantlist.org/ [accessed October 2018].

Thomas N, Bruhl JJ, Ford A, Weston PH. 2014. Molecular dating of Winteraceae reveals a complex biogeographical history involving both ancient Gondwanan vicariance and longdistance dispersal. J. Biogeogr. 41: 894-904. DOI: 10.1111/jbi.12265.

Upchurch GR, Dilcher DL. 1990. Cenomanian angiosperm leaf megafossils, Dakota Formation, Rose Creek locality, Jefferson County, southeastern Nebraska. U.S. Geol. Survey Bull. 1915.

Valentin X, Gomez B, Daviero-Gomez V, Charbonnier S, Ferchaud P, Kirejtshuk AG, Licht A, Néraudeau D, Vullo R, Garcia G. 2014. Plant-dominated assemblage and invertebrates from the lower Cenomanian of Jaunay-Clan, western France. C.R. Palevol. 13: 443-454. https://doi.org/10.1016/j.crpv.2014.04.001.

Walker JW, Brenner GJ, Walker AG. 1983. Winteraceous pollen in the Lower Cretaceous of Israel: early evidence of a magnolialean angiosperm family. Science 220 (4603): 12731275. DOI: $10.1126 /$ science.220.4603.1273.

Walker JW, Walker AG. 1984. Ultrastructure of Lower Cretaceous angiosperm pollen and the origin and early evolution of flowering plants. Ann. Mo Bot. Gard. 71: 464-521. https:// doi.org/10.2307/2399035.

Wheeler EA. 2011. InsideWood - a web resource for hardwood anatomy. IAWA J. 32: 199_ 211. DOI: $10.1163 / 22941932-90000051$.

Young DA. 1981. Are the angiosperms primitively vesselless? Syst. Bot. 6: 313-330. DOI: $10.2307 / 2418445$. 